\title{
SPECYFIKA METODYKI PRZEPROWADZANIA OCENY ODDZIAŁYWANIA NA OBSZAR NATURA 2000 INWESTYCJI BUDOWLANEJ W ŚWIETLE BADAŃ WŁASNYCH
}

\author{
Jolanta Harasymiuk ${ }^{\bowtie}$ \\ Wydział Geodezji Inżynierii Przestrzennej i Budownictwa, Uniwersytet Warmińsko Mazurski w Olsztynie, Olsztyn
}

\begin{abstract}
STRESZCZENIE
Celem artykułu jest analiza metodyki przeprowadzania oceny oddziaływania inwestycji budowlanych na obszar Natura 2000. Obszary Natura 2000 stanowią najmłodszą z form ochrony przyrody, wprowadzoną do krajowego systemu prawnego w następstwie przystapienia Polski do Unii Europejskiej. Są one wyznaczane we wszystkich państwach członkowskich Unii w celu utworzenia europejskiej sieci ekologicznej terenów o najcenniejszych walorach przyrodniczych, co nakłada na inwestorów istotne ograniczenia w możliwościach i sposobach ich zabudowy. Nieznajomość wymogów formalnoprawnych i metodycznych towarzyszących procesowi oceny może skutkować nieuzyskaniem decyzji zezwalającej na realizację inwestycji budowlanej lub wydłużeniem czasu potrzebnego na przygotowanie inwestycji do realizacji. W artykule określono i scharakteryzowano etapy i fazy oceny oddziaływania na obszar Natura 2000 z perspektywy inwestora wraz z zasygnalizowaniem najnowszych zmian wynikających ze znowelizowanej ustawy o udostępnianiu informacji o środowisku, udziale społeczeństwa w ochronie środowiska oraz ocenach oddziaływania na środowisko, a także z potencjalnych zagrożeń dla uzyskania satysfakcjonującego inwestora rozstrzygnięcia. Wskazano również wynikające z przepisów niedostatki metodyczne wyodrębnionych faz.
\end{abstract}

Słowa kluczowe: Natura 2000, obszar Natura 2000, ocena oddziaływania przedsięwzięcia na obszar Natura 2000, inwestycja budowlana, ocena właściwa

\section{WSTĘP}

Przepisy ochrony środowiska nakładają na inwestora obowiązek poddania ocenie oddziaływania na obszar Natura 2000 przedsięwzięcia planowanego do realizacji na takim obszarze lub w jego sąsiedztwie. Przez ocenę oddziaływania inwestycji budowlanej na obszar Natura 2000 należy rozumieć ocenę oddziaływania tej inwestycji na środowisko, ograniczoną do badania jej oddziaływania na taki obszar. W literaturze ocena ta jest również określana mianem oceny habitatowej (Montini, 2001; Rakoczy i Pchałek, 2010; Jendrośka i Jerzmański, 2011) lub siedliskowej (Engel, 2009).

Realizacja zobowiązania inwestora wiąże się z przejściem przez wszystkie stadia skomplikowanej procedury administracyjnej, w której można wyodrębnić ocenę wstępną i właściwą. W ramach oceny wstępnej ma miejsce zainicjowanie całej procedury. Organ właściwy do wydania decyzji zezwalającej na realizację inwestycji budowlanej, np. organ wykonawczy gminy, ma obowiązek rozważenia przed wydaniem decyzji o warunkach zabudowy i zagospodarowania terenu, czy konkretne zamierzenie budowlane może znacząco oddziaływać na

\footnotetext{
凶jolanta.harasymiuk@uwm.edu.pl
} 
obszar Natura 2000. Jeżeli uzna to za prawdopodobne, to nakłada na inwestora obowiązek złożenia wniosku o stwierdzenie zasadności oceny siedliskowej do właściwego regionalnego dyrektora ochrony środowiska. W ramach oceny właściwej dokonuje się m.in.: identyfikacji potencjalnych oddziaływań inwestycji, identyfikacji i oceny oddziaływań znaczących, wskazania i oceny środków łagodzących.

W literaturze zagadnienie oceny wstępnej i właściwej nie zostało wystarczająco opisane (Kasztelewicz i Ptak, 2009; Rak, 2014; Gawrońska i Ostrowiak, 2015; Harasymiuk, 2016), tymczasem obydwa rodzaje oceny są kluczowe z punktu widzenia osiagnięcia celu oceny siedliskowej, jakim jest wykluczenie wystapienia negatywnego znaczącego oddziaływania inwestycji budowlanej na obszar Natura 2000. Specyfika metodyki oceny wstępnej, która pozwala na ograniczenie liczby prowadzonych postępowań „ocenowych” w stosunku do przedsięwzięć bardziej szkodliwych dla środowiska, zostanie przedstawiona w kolejnym artykule.

W niniejszym opracowaniu podjęto próbę usystematyzowania oceny właściwej oddziaływania inwestycji budowlanej na obszar Natura 2000. Scharakteryzowano etapy i fazy oceny oraz towarzyszące im zakresy działań inwestora, regionalnego dyrektora ochrony środowiska, organu zezwalającego na realizację inwestycji i społeczeństwa.

\section{MATERIAt I METODY}

Główne zasady przeprowadzania oceny siedliskowej zawarte są w Ustawie z dnia 3 października $2008 \mathrm{r}$. o udostępnianiu informacji o środowisku i jego ochronie, udziale społeczeństwa w ochronie środowiska oraz ocenach oddziaływania na środowisko (Dz.U. 2013 poz. 1235). Mają tu również zastosowanie regulacje zawarte w Ustawie z dnia 14 czerwca 1960 r. - Kodeks postępowania administracyjnego (Dz.U. $2000 \mathrm{nr}$ 98, poz. 1071 z późn. zm.) oraz w innych aktach prawnych, np. w Ustawie z dnia 7 lipca 1994 r. - Prawo budowlane (Dz.U. 2016 poz. 290), Ustawie z dnia 16 kwietnia 2004 r. o ochronie przyrody (Dz.U. $2004 \mathrm{nr}$ 92, poz. 880, z późn. zm.), Ustawie z dnia 27 kwietnia 2001 r. - Prawo ochrony środowiska (Dz.U. 2013 poz. 1232), Ustawie z dnia 14 grudnia 2012 r. o odpadach (Dz.U.2013 poz. 21), Ustawie z dnia 18 lipca 2001 r. - Prawo wodne (Dz.U. 2013 poz. 627)).

Przedmiotem niniejszego opracowania jest analiza metodyki przeprowadzania oceny właściwej oddziaływania inwestycji budowlanej na obszar Natura 2000. Realizacja założonego celu była możliwa dzięki przeprowadzeniu kwerendy archiwalno-bibliotecznej (która objęła: literaturę przedmiotu, akty prawne odnoszące się do oceny siedliskowej oraz dokumentację postępowań administracyjnych prowadzonych w latach 2013 -2015 przez Regionalną Dyrekcję Ochrony Środowiska w Olsztynie) oraz sondażu wśród ekspertów - pracowników uczestniczących w wykonywaniu wymienionych ocen.

\section{WYNIKI}

\section{Analiza oceny właściwej oddziaływania przedsięwzięcia na obszar Natura 2000}

Rozpoczęcie oceny właściwej oddziaływania inwestycji budowlanej na obszar Natura 2000 może nastąpić w dwóch przypadkach: jako następstwo wniosku o konieczności jej przeprowadzenia, jaki pojawił się na zakończenie oceny wstępnej, lub w wyniku rezygnacji z oceny wstępnej, gdy możliwość znaczącego oddziaływania przedsięwzięcia na obszar(y) Natura 2000 jest tak ewidentna, że można od razu przejść do oceny właściwej (Engel, 2009).

Ocena właściwa składa się z szeregu logicznie powiązanych czynności, które można pogrupować w pięć zasadniczych faz:

A. Kwalifikacja inwestycji budowlanej jako przedsięwzięcia mogącego znacząco oddziaływać na obszar Natura 2000 i ustalenie zakresu raportu.

B. Przygotowanie raportu o oddziaływaniu przedsięwzięcia na obszar Natura 2000. 
C. Weryfikacja (kontrola jakości) raportu.

D. Konsultacje społeczne rozwiązań przyjętych w raporcie.

E. Wydanie/odmowa wydania postanowienia uzgadniającego warunki realizacji przedsięwzięcia.

\section{KWALIFIKACJA INWESTYCJI BUDOWLANEJ DO PRZEPROWADZENIA POSTĘPOWANIA "OCENOWEGO”I USTALENIE ZAKRESU RAPORTU}

Kwalifikacja inwestycji jako przedsięwzięcia mogącego znacząco oddziaływać na obszar Natura 2000 stanowi ważny etap całej procedury. To właśnie wtedy następuje ustalenie, czy ocena jest zasadna i powinna zostać przeprowadzona. Wydanie stosownego rozstrzygnięcia powinno poprzedzać zebranie odpowiednich i wystarczających danych dotyczących planowanej inwestycji i obszaru(ów) Natura 2000. Wymagane są trzy rodzaje dokumentów: opracowania przygotowywane przez inwestora lub na jego zlecenie (np. karta informacyjna przedsięwzięcia ${ }^{1}$, wniosek o decyzję wzizt wraz z wymaganymi załącznikami), opracowania planistyczne na poziomie gminnym i wojewódzkim, dane i opracowania zawierające informacje o zasobach przyrodniczych i przebiegu granic obszarów (interaktywna mapa obszarów Natura 2000, standardowe formularze danych obszarów Natura 2000, poradnik ochrony siedlisk i gatunków Natura 2000, t. 1-9, plany ochrony i plany zadań ochronnych, inwentaryzacje siedlisk i gatunków wykonywane przez Lasy Państwowe oraz Generalną Dyrekcję Ochrony Środowiska, protokoły z wizji terenowych, dokumentacja archiwalna z innych postępowań).

Rzetelna analiza tak różnorodnych dokumentów wymaga od urzędników prowadzących postępowania interdyscyplinarnej wiedzy z zakresu nauk inżynierskich, przyrodniczych i prawnych. Stawia to wysokie wymagania merytoryczne osobom wykonującym tego typu zadania.

W procedurze kwalifikacji przedsięwzięć do sporządzenia raportów dotyczących oddziaływania na obszar Natura 2000 nie stosuje się spójnego systemu merytorycznych kryteriów. Stosowane są uwarunkowania sformułowane w art. 97.1 Ustawy (2008): charakterystyka przedsięwzięcia, jego lokalizacja oraz potencjalne oddziaływanie. $\mathrm{Z}$ analizy uzasadnień do postanowień regionalnego dyrektora ochrony środowiska w Olsztynie $\mathrm{z}$ lat 2013-2015, nakładających na inwestorów obowiązek przeprowadzenia oceny siedliskowej dla inwestycji budowlanych, wynika brak odniesienia do wszystkich ustawowych uwarunkowań kwalifikacji. W większości uzasadnień można znaleźć odniesienie do jednego z nich - lokalizacji przedsięwzięcia względem obszarów ochrony przyrody. Dobrą praktyką było natomiast rozważanie kumulacji oddziaływań ze strony przedsięwzięć znajdujących się na terenach sąsiednich z oddziaływaniami planowanych inwestycji budowlanych, jeszcze przed wejściem przepisów nowelizujących Ustawę z dnia 3 października 2008 r. o udostępnianiu informacji o środowisku i jego ochronie, udziale społeczeństwa w ochronie środowiska oraz ocenach oddziaływania na środowisko.

Brak informacji o gatunkach chronionych na podstawie przedłożonej przez inwestora informacji jest zawsze rozstrzygany „na niekorzyść inwestora” i skutkuje wydaniem opinii o obowiązku sporządzenia raportu. Do dnia dzisiejszego brakuje precyzyjnego określenia elementów, które powinny się znaleźć w raporcie². Zachodzi więc potrzeba każdorazowego określania zakresu tego dokumentu przez urzędników prowadzących postępowanie.

\footnotetext{
${ }^{1}$ Karta informacyjna przedsięwzięcia to dokument stanowiący podstawę kwalifikacji inwestycji do procedury oceny oddziaływania na obszar Natura 2000. Od wiarygodności i jakości zawartych w nim informacji zależy rodzaj rozstrzygnięcia (odrzucenie lub akceptacja inwestycji) oraz zakres nałożonych na inwestora wymogów środowiskowych, koniecznych do uwzględnienia w projekcie budowlanym oraz w trakcie realizacji prac budowlanych. Od 1 stycznia 2017 roku wymagania dotyczące zawartości karty zostały rozszerzone i zawarte w nowym art. 62a znowelizowanej Ustawy (2008).

${ }^{2}$ Ustawa (2008) w art. 66 określa obligatoryjne elementy raportu o oddziaływaniu przedsięwzięcia na środowisko, wskazując jednocześnie (art. 97 ust. 4), że zakres raportu o oddziaływaniu przedsięwzięcia na obszar Natura 2000 powinien być zawężony do określenia oddziaływania inwestycji budowlanej na ten obszar.
} 
Oprócz ogólnej charakterystyki inwestycji, inne istotne kwestie merytoryczne, które formułowane były w zakresach raportów o oddziaływaniu inwestycji budowlanych na obszar natura 2000, dotyczyły:

- opisu elementów przyrodniczych istniejących w zasięgu oddziaływania planowanej inwestycji,

- oceny wpływu inwestycji na stan, przedmioty ochrony oraz integralność obszaru(ów) Natura 2000,

- opisu wariantów realizacji inwestycji (technicznego, środowiskowego i „,zerowego”) wraz z uzasadnieniem wariantu wybranego przez inwestora w przypadku stwierdzenia oddziaływania inwestycji na obszar Natura 2000 ,

- przedstawienia w formie graficznej strefy oddziaływania inwestycji oraz lokalizacji zinwentaryzowanych zasobów środowiska,

- wniosków określających, czy planowana inwestycja może osobno lub w połączeniu z innymi przedsięwzięciami pogorszyć stan siedlisk przyrodniczych lub gatunków roślin i zwierząt, dla których ochrony wyznaczono obszar(y) Natura 2000,

- opisu wymaganych działań zapobiegawczych lub kompensacyjnych,

- zakresu i terminów przeprowadzenia inwentaryzacji terenowej występowania gatunków ptaków i siedlisk chronionych.

Wymaga się, aby oddziaływania planowanych inwestycji były klasyfikowane pod względem zasięgu przestrzennego oraz czasowego i identyfikowane jako: bezpośrednie, pośrednie, wtórne, krótko-, średnio- i długoterminowe, stałe i chwilowe. W tabeli 1 przedstawiono uogólnione, przykładowe typy oddziaływań inwestycji związanej z budowa jednorodzinnego budynku mieszkalnego. Tabela ma charakter wyłącznie poglądowy, ponieważ środowiskowe skutki inwestycji takiego samego rodzaju mogą być różne w różnych lokalizacjach.

Tabela 1. Przykładowe, uogólnione typy oddziaływań na środowisko związane z budową jednorodzinnego budynku mieszkalnego (opracowanie własne)

Table 1. Exemplary, generalized types of environmental impacts associated with the construction of single-family residential building (authors`own elaboration)

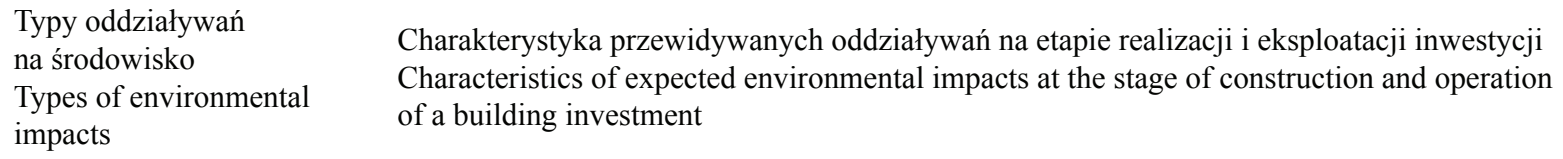

Charakterystyka przewidywanych oddziaływań na etapie realizacji i eksploatacji inwestycji Characteristics of expected environmental impacts at the stage of construction and operation of a building investment

Pośrednie i wtórne Intermediate and secondary

Krótkoterminowe Short-term

Średnioterminowe Intermediate

Długoterminowe

Long-term

Likwidacja powierzchni biologicznie czynnej wraz z florą obszaru przeznaczonego pod budowę budynków

Liquidation of the biologically active surface along with the flora of the building ground

Zniszczenie flory poprzez zajęcie terenu pod budynek

Destroying of the flora in the area designed for a building

Emisja hałasu związana z pracą ciężkiego sprzętu budowlanego do robót ziemnych i montażowych

Noise emission related to work of heavy construction equipment dedicated to groundwork or assembly work

Emisja hałasu i zanieczyszczeń do powietrza, powstanie odpadów w związku z budową budynku Noise emission and air pollution, wastes arising from the construction of a building

Zmieniony krajobraz w związku z organizacją placu budowy, postojem maszyn i gromadzeniem materiałów budowlanych

Altered landscape due to organization of a building site, standing of construction equipment and gathering of construction wastes

Emisja hałasu przez mieszkańców budynku

Noise emission by the occupants of the building 


\begin{tabular}{|c|c|}
\hline Odwracalne & Czasowa degradacja flory związana z prowadzeniem robót budowlanych \\
\hline Reversible & Temporary degradation of the flora related to carrying building works \\
\hline Stałe & Związane z użytkowaniem powstałego budynku \\
\hline Constant & Related to the maintenance of a building \\
\hline \multirow{2}{*}{$\begin{array}{l}\text { Chwilowe } \\
\text { Temporary }\end{array}$} & $\begin{array}{l}\text { Wynikające z awarii maszyn podczas budowy projektowanego budynku (rozlanie substancji ro- } \\
\text { popochodnych) }\end{array}$ \\
\hline & Resulting from machine failures during the construction of a building (for example: fuel/oil spill) \\
\hline Skumulowane & $\begin{array}{l}\text { Oddziaływanie planowanej zabudowy wraz z istniejącą dotychczas oraz projektowaną zabudową } \\
\text { rozproszona }\end{array}$ \\
\hline Cumulated & $\begin{array}{l}\text { Interaction of planned land development along with an already existing and designed dispersed } \\
\text { development }\end{array}$ \\
\hline
\end{tabular}

Nie stosuje się jednolitych kryteriów pozwalających na ocenę, czy dane oddziaływanie powoduje negatywne skutki o charakterze istotnym. O istotności oddziaływań planowanych inwestycji decyduje się, stosując metodę oceny indywidualnej. Zazwyczaj brana jest pod uwagę wrażliwość siedlisk i gatunków na działanie czynników zewnętrznych oraz cechy przedsięwzięcia i jego oddziaływań (rozmiar, czas trwania, natężenie, odwracalność, efekt kumulacji z oddziaływaniami innych przedsięwzięć). Podstawowym zadaniem raportu dotyczącego oddziaływania inwestycji na obszar(y) Natura 2000 jest wykazanie, jakie ewentualne oddziaływanie na integralność i spójność tego/tych obszaru(ów) może mieć realizacja i eksploatacja planowanej inwestycji budowlanej. Pojęcie to, chociaż zdefiniowane w Ustawie (2004), nadal przysparza problemów interpretacyjnych inwestorom, organom odpowiedzialnym za dokonanie oceny oraz autorom samych raportów. Najcześciej pod pojęciem integralności obszaru rozumie się jego wewnętrzną spoistość, czyli niski stopień defragmentacji. Takie rozumienie tego pojęcia może jednak prowadzić do mylnego przekonania, że szkodliwa jest tylko taka inwestycja, która dzieli obszar na kilka części.

Pod pojęciem integralności obszaru należy również rozumieć utrzymywanie się właściwego stanu ochrony siedlisk przyrodniczych oraz populacji roślin i zwierząt, dla których ochrony dany obszar został wyznaczony (Engel, 2009).

\section{Weryfikacja (kontrola jakości) raportu}

Raport o oddziaływaniu inwestycji na obszar Natura 2000 to szczególny rodzaj ekspertyzy środowiskowej, która powinna charakteryzować się wysokimi walorami merytorycznymi. Regionalny dyrektor ochrony środowiska, określając zakres raportu, musi poruszać się w ramach określonych Ustawą (2008). Brak precyzyjnych wymagań w tym zakresie może prowadzić do różnej interpretacji wynikającego z przepisów tej ustawy „spisu treści” raportu. Sprawdzenie kompletności i spójności raportu dokonywane jest poprzez porównanie sformułowanego w postanowieniu regionalnego dyrektora ochrony środowiska zakresu raportu z treścią dokumentu opracowaną na zlecenie inwestora. Stosowana jest metoda oceny indywidualnej, która nawet jeżeli jest wspomagana lista kontrolną do oceny zawartości merytorycznej raportu w indywidualnych przypadkach, to nie jest to praktyka powszechnie obowiązująca.

Nowelizacja Ustawy (2008) zakłada m.in.: wymóg uwzględniania wyników inwentaryzacji przyrodniczej w formie załączników do raportów, wymóg podania źródeł danych, na podstawie których dokonywany był opis elementów przyrodniczych, obowiązek odniesienia się w raportach do celów środowiskowych wskazanych $\mathrm{w}$ dokumentach strategicznych, istotnych z punktu widzenia realizacji konkretnych inwestycji budowlanych. Autorami raportów o ocenach oddziaływania na środowisko będą mogły być osoby z odpowiednim wykształ- 
ceniem lub doświadczeniem. W przypadku gdy raport jest przygotowywany przez zespół autorów, kwalifikacje określone w ustawie musi posiadać przynajmniej kierujący tym zespołem (Oceny oddziaływania na środowisko po nowemu, 2016). Od 1 stycznia 2017 roku jednym z elementów raportu jest oświadczenie autora (lub kierującego zespołem) o spełnieniu wymagań ustawowych dotyczących kwalifikacji, składane pod rygorem odpowiedzialności karnej za składanie fałszywych oświadczeń.

\section{Konsultacje społeczne}

Po akceptacji raportu, regionalny dyrektor ochrony środowiska występuje do organu, który zainicjował całe postępowanie, o zapewnienie możliwości udziału społeczeństwa. Ten, po otrzymaniu raportu, zapewnia: powiadomienia o kolejnych etapach postępowania, możliwość wglądu do raportu oraz złożenie uwag i wniosków. W przypadku przedsięwzięć budzących duży opór społeczny, a do takich zaliczane są inwestycje podlegające postępowaniu w sprawie oceny oddziaływania na obszar Natura 2000, może mieć miejsce podważanie ustaleń zawartych w raporcie. Krytyczne uwagi wobec raportu mogą wyrazić pozostałe strony postępowania, organizacje ekologiczne, przedstawiciele lokalnej społeczności. Raport przygotowywany jest na zlecenie inwestora, a więc istnieje ryzyko, że może być nieobiektywny. Przedłużenie terminu z 21 do 30 dni ma sprawić, że udział społeczeństwa w postępowaniach środowiskowych stanie się bardziej realny. Wydłużenie terminu konsultacji społecznych jest niewielkie ( 9 dni), jednak czas trwania całego postępowania może się wydłużyć. Jeżeli w jego toku zajdzie konieczność uzupełnienia raportu, to organ wykonawczy gminy (w przypadku decyzji wzizt) ma obowiązek wielokrotnego wyznaczania nowego 30-dniowego terminu na składanie uwag i wniosków.

\section{Wydanie postanowienia uzgadniającego warunki realizacji przedsięwzięcia}

W przeciwieństwie do tradycyjnej oceny oddziaływania na środowisko, ocena habitatowa musi być przeprowadzona w formie uzgodnienia. Po zapewnieniu udziału społeczeństwa organ wykonawczy gminy odpowiedzialny za wydanie decyzji zezwalającej na realizację inwestycji budowlanej przekazuje do regionalnego dyrektora ochrony środowiska zgłoszone uwagi i wnioski społeczeństwa, w tym protokół z rozprawy administracyjnej otwartej (jeżeli była przeprowadzana). Ten w terminie 45 dni od otrzymania raportu powinien wydać postanowienie uzgadniające warunki realizacji przedsięwzięcia. Jeżeli w toku oceny zostanie wykazane znaczące oddziaływanie na obszar Natura 2000 albo takiego oddziaływania nie da się wykluczyć, to inwestycja nie może zostać zrealizowana. W takim przypadku regionalny dyrektor ochrony środowiska odmawia wyrażenia zgody na realizację inwestycji, która została oceniona jako przedsięwzięcie mogące znacząco negatywnie oddziaływać na obszar Natura 2000. Wyjątkiem jest inwestycja, dla której nie istnieją rozwiązania alternatywne, która powinna być zrealizowana z uwagi na konieczne wymogi nadrzędnego interesu publicznego (brak precyzyjnej definicji tego pojęcia) oraz której negatywne oddziaływanie na integralność obszaru i jego przedmioty ochrony zostanie zrekompensowane działaniami na rzecz zachowania spójności całej sieci Natura 2000.

\section{PODSUMOWANIE I WNIOSKI}

Ocena oddziaływania inwestycji budowlanej na obszar Natura 2000 wykazuje swoją specyfikę, którą trudno zrozumieć inwestorom zobligowanym do poddania swoich zamierzeń budowlanych postępowaniom ,ocenowym". Zjawisko to potęgują nieprecyzyjne, często zmieniające się przepisy, które nie stawiają jednoznacznych wymagań w zakresie zasad dokonywania takiej oceny.

Przeprowadzona analiza wskazuje na nieprzejrzystość metodyki oceny oddziaływania inwestycji budowlanych na obszar(y) Natura 2000 w fazach: kwalifikacji inwestycji budowlanych do przeprowadzenia oceny siedliskowej, przygotowania raportu o oddziaływaniu przedsięwzięcia na obszar Natura 2000 oraz jego weryfikacji. Nieprzejrzystość ta może wpłynąć na wydłużenie procesu inwestycyjnego oraz utrudnić inwestorowi uzyskanie satysfakcjonującego go rozwiązania w postaci zezwolenia na realizację inwestycji budowlanej. 
Harasymiuk, J. (2017). Specyfika metodyki przeprowadzania oceny oddziaływania na obszar Natura 2000 inwestycji budowlanej w świetle badań własnych. Acta Sci. Pol. Architectura, 16 (2), 47-54. doi: 10.22630/ASPA.2017.16.2.06.

Kwalifikowanie przedsięwzięcia do oceny siedliskowej powinno się odbywać na podstawie zbioru ustalonych kryteriów w miejsce wynikających z Ustawy (2008) ogólnych uwarunkowań.

Zasadne jest wypracowanie narzędzia (w postaci wytycznych metodycznych, list sprawdzających), które byłoby stosowane w praktyce do oceny zawartości merytorycznej kart informacyjnych i raportów.

W celu precyzyjnego oszacowania wielkości oddziaływań ze strony przedsięwzięcia oraz właściwej identyfikacji oddziaływań znaczących wskazane jest, aby oddziaływania te charakteryzowane były w sposób opisowy (listy sprawdzające) i ilościowy oraz z zastosowaniem obiektywnych wskaźników.

\title{
PIŚMIENNICTWO
}

Engel, J. (2009). Natura 2000 w ocenach oddziaływania przedsięwzięć na środowisko. Warszawa: Ministerstwo Środowiska.

Gawrońska, G. i Ostrowiak, S. (2015). Weryfikacja oceny oddziaływania na środowisko kopalni piasku wydmowego „Wilcza Wola" w województwie podkarpackim. Acta Scientiarum Polonorum, Formatio Circumiectus, 14(2), 65-79.

Harasymiuk, J. (2016). Wybrane problemy uzyskiwania zezwoleń na realizację inwestycji budowlanych na obszarach Natura 2000 w województwie warmińsko-mazurskim. Warszawa: Politechnika Warszawska.

Jendrośka, J. i Jerzmańskli, J., red. (2011). Prawo ochrony środowiska dla praktyków. Tom 3. Warszawa: Wydawnictwo Verlag Dashofer.

Kasztelewicz, Z. i Ptak, M. (2009). Procedura oceny oddziaływania na środowisko w górnictwie odkrywkowym, w świetle nowych regulacji ze szczególnym uwzględnieniem specyfiki obszarów Natura 2000. W Materiały sympozjum z cyklu „Zagrożenia naturalne w górnictwie”, 60-76.

Montini, M. (2001). Habitats Impact Assessment: an Effective Instrument for Biodiversity Conservation. Environmental Liability, 9(4), 182-187.

Oceny oddziaływania na środowisko po nowemu (2016). Pobrano z lokalizacji: http://www.codozasady.pl/wp-content/uploads/2016/09/Wardynski-i-Wspolnicy_-Oceny-oddzialywania-na-srodowisko.pdf (dostęp: 15.01.2017).

Rak, A. (2014). Budowlane przedsięwzięcia inwestycyjne. Środowiskowe uwarunkowania przygotowania i realizacji. Warszawa: Wydawnictwo Naukowe PWN.

Rakoczy, B. i Pchałek, M. (2010). Wybrane problemy prawa ochrony środowiska. Warszawa: Oficyna Wolters Kluwer business.

Ustawa z dnia 14 czerwca 1960 r. - Kodeks postępowania administracyjnego (Dz.U. 2000 nr 98, poz. 1071 z późn. zm.).

Ustawa z dnia 7 lipca 1994 r. - Prawo budowlane (tekst jednolity Dz.U. 2016, poz. 290).

Ustawa z dnia 27 kwietnia 2001 r. - Prawo ochrony środowiska (tekst jednolity Dz.U. 2013 poz. 1232).

Ustawa z dnia 18 lipca 2001 r. - Prawo wodne (tekst jednolity Dz.U. 2013 poz. 627).

Ustawa z dnia 16 kwietnia 2004 r. o ochronie przyrody (Dz.U. 2004 nr 92, poz. 880 ze zm.).

Ustawa z dnia 3 października 2008 r. o udostępnianiu informacji o środowisku i jego ochronie, udziale społeczeństwa W ochronie środowiska oraz ocenach oddziaływania na środowisko (tekst jednolity Dz.U. 2013 poz. 1235).

Ustawa z dnia 14 grudnia 2012 r. o odpadach (Dz.U. 2013 poz. 21).

\section{THE SPECIFICS OF THE METHODOLOGY OF CONDUCTING AN ASSESSMENT OF THE IMPACT OF BUILDING INVESTMENT IN THE AREA OF NATURA 2000 IN LIGHT OF OWN RESEARCH}

\begin{abstract}
The aim of the article is the analysis of the mythology of conducting an assessment of the impact of a building investment in the area of Natura 2000. The areas of Natura 2000 is the newest form of the environmental protection, introduced into the Polish legal system as a result of Poland joining the EU. There are delineated in all the member states of the EU, with the aim of creating an ecological network of the most valuable natural
\end{abstract}


areas, which strongly restricts the investors' opportunities and ways of construction projects. The ignorance of the formal legal and methodological requirements accompanying the process of the assessment may result in the failure to obtain permission for the completion of the building project or the prolongation which is required to prepare an investment for completion. In the article the stages of an assessment of the impact on the Natura 2000 areas were determined and characterized from the viewpoint of the investor with the indication of the newest changes which issue from the renewed act of parliament on giving access to information on the environment, on the societal participation in the environmental protection, and on the assessment of the environmental impact, and the potential threats to a positive decision for the investor. The methodological shortcomings of the delineated stages which issue from the legal regulation were also indicated.

Key words: Natura 2000, area of Natura 2000, assessment of the impact of investment in the area of Natura 2000 , building investment, proper assessment 